\title{
A REVIEW OF LABORATORY ANIMAL EXPERIMENTS RELATED TO THE RADIOBIOLOGY OF TRITIUM
}

\author{
By
}

Roy C. Thompson

Biology Department

\author{
Battelle Memorial Institute \\ Pacific Northwest Laboratory \\ Richland, Washington
}

This report was prepared as an account of work sponsored by the United States Government. Neither the United States nor the United States Atomic Energy Commission, nor any of their employees, nor any of their contractors, subcontractors, or their employees, makes any warranty, express or implied, or assumes any legal liability or responsibility for the accuracy, completeness or usefulness of any information, apparatus, product or process disclosed, or represents that its use would not infringe privately owned rights.
May 1971

*This paper is based on work performed under U. S. Atomic Energy Commission Contract AT(45-1)-1830. 


\section{DISCLAIMER}

This report was prepared as an account of work sponsored by an agency of the United States Government. Neither the United States Government nor any agency Thereof, nor any of their employees, makes any warranty, express or implied, or assumes any legal liability or responsibility for the accuracy, completeness, or usefulness of any information, apparatus, product, or process disclosed, or represents that its use would not infringe privately owned rights. Reference herein to any specific commercial product, process, or service by trade name, trademark, manufacturer, or otherwise does not necessarily constitute or imply its endorsement, recommendation, or favoring by the United States Government or any agency thereof. The views and opinions of authors expressed herein do not necessarily state or reflect those of the United States Government or any agency thereof. 


\section{DISCLAIMER}

Portions of this document may be illegible in electronic image products. Images are produced from the best available original document. 


\section{及NWh: SA- 2739 CoN.f- $710508--3$}

A REVIEW OF .LABORATORY ANIMAL. EXPERIMENTS

RELATED TO THE RADIOBIOLOGY OF TRITIUM

By

Roy C. Thompson

The preparation of this paper has given me an opportunity to catch up on developments in a field in which I have not been personally active for a number of years. I've felt a little guilty about passing myself off as an expert, under these circumstances, but; I can easily rationalize. my position by noting that I have an obviously open mind and can; therefore, be totally objective.

Let me first describe the assignment, as I have interpreted it. I shall be concerned with laboratory animal experiments, which excludes all studies of environmental tritium. The general theme of this symposium--this whole meeting actually--has been radiation protection standards for man, and this emphasis will also serve to narrow my coverage. I shall confine myself to those studies relevant to important human hazard concerns, neglecting strictly tracer studies and studies with particular compounds, such as tritiated thymidine, which, are not a hazard of concern to large numbers of people.

One can recognize two general types of laboratory animal studies with tritium, which are of interest.to us in this narrowed context. There are studies of tritium metabolism, which tell us where tritium goes in the animal, and how long it stays, and from which we may calculate radiation dose rates and infer biological effects. And there are studies of tritium toxicity which tell us directly what may happen to animals and 
presumably man, if éxposed to sufficiently high levels of tritium, under the experimentally investigated conditions. Rather than attempt to catalog these animals experiments, I propose to state my conclusions in various areas, and support these conclusions by reference to some of the more interesting and pertinent experiments. While perhaps lacking in objectivity and scientific rigor this approach seemed the only way to cover the field while still allowing some opportunity to dwell upon the more interesting observations.

In keeping with this plan of attack, I would like to now state my general conclusion. Animal experiments conducted over the past 20 years have demonstrated no unusual metabolic behavior of tritium that would not have been fiirly confidently predicted before these experiments were conducted; nor have the effects of tritium observed in animals differed from those which might have been predicted from a general knowledge of the effects of ionizing radiation. This lack of surprises should, itself, not be surprising. Tritium is, after all, an isotope of hydrogen, which is the simplest element and probably the most studied and best known element. Tritium oxide, the compound of principal hazard concern, is water; and water must be, by all odds, the most studied and best known of all compounds. It would indeed be surprising if we had not been able to make some pretty good predictions about tritium hazards.

Which is not to say that hazard evaluation studies with tritium during the past 20 years have been a waste of time, or that there are not still experiments that should be done. In no areas of radiation hazard evaluation can we predict with such confidence that experimental 
validation of those predictions is not desirable. It must also be acknowledged that tritium has proved to be a very powerful tool in the study of the metabolism of hydrogen and of water and we have learned some new and interesting things about hydrogen and its compounds through the use of tritium.

What, then, are some of the more significant animal experiments with tritium.

First, let us consider, and quickly dispose of elemental tritium. : Elemental tritium is so much less hazardous than tritium oxide that nobody worries much about it; particularly since it is difficult to distinguish between tritium gas and tritium oxide, and one must usually assume that . any measured tritium is tritium oxide. While inhaled tritium oxide is $100 \%$ retained, inhaled elemental tritium is $99.9 \%$ exhaled by rats, $(1,2)$ and even lower retention has been reported for humans (2). Such retention as does occur seems to be due primarily to bacterial conversion of the tritium to tritium oxide (1). The retention of elemental tritium absorbed through the skin has been shown to be of less significance, even, than that of inhaled elemental tritium (3). The remainder of this talk will; therefore, be concerned with tritium oxide--metabolism and effects. With regard to routes of entry of tritium oxide, the situation is quite simple. It was early demonstrated that ingested or inhaled tritium oxide was quickly and totally absorbed and equilibrated with body water $(2,4,5)$. Somewhat more surprising was the observation of the high rates of tritium oxide movement through the intact skin. That water moves across 
the skin barrier was no surprise, but the magnitude of the unidirectional flux was not known until measured with tritium oxide (6). Since this poses a practical exposure control problem that has received much attention in accidentally and purposefully exposed humans, it will no doubt be considered by $\mathrm{Dr}$. Osborne, and let me limit my remarks to simply pointing out that rodents $(2,4,6,7)$ or man, exposed in a tritium oxide vapor atmosphere will absorb about as much tritium thru:their skin as thru their lungs. Recent frog skin studies have shown no isotope effect, as between deuterium and tritium oxides, in skin permeability (8).

Damage from tritium in the body will depend upon where it is in the body and how long it stays there. Most of it, is present as water, and how long it stays will depend upon the turnover rate of body water. There have been many studies of body water turnover in animals--which are of not much interest to us in our present context, because we are concerned with the hazard to man and there are many studies of body water turnover in man. We needn't extrapolate from animal data. But, just by way of example let's look at some rather interesting comparative animal data published quite a few years ago by the chairman of this symposium (9). First slide, please.

SLIDE 1 From a $20 \mathrm{~g}$ mouse to a $400,000 \mathrm{~g}$ horse, we see not very much variation from a $60 \%$ body water figure, and a generally increasing turnover time with larger animal size, though the kangaroo rat, adapted as it is to low water consumption, is an interesting exception to the general trend. 
DE 2 Another example of the treatment of this data, on the next slide, shows the logarithm of water loss per day to be a reasonably linear function of the logarithm of body 'weight--the kangaroo rat, again, falling outside the pale. Having shown some of Chet's data, I would now like to show some of mine and then we can forget about slides.

SLIDE 3

The next slide shows a typical retention curve for tritium in the body water of rats. For perhaps 40 days following a single injection of tritium oxide we see this exponential decline in activity over a $1000-$ fold concentration range. This corresponds to the approximately 3-day half-time for body water turnover in the rat. A small fraction of tritium, however, is retained with a much longer half-time. This is presumably tritium released to body water from organic compounds in which it was incorporated. This might be of special hazard concern, because it is retained much longer than body water tritium.

SLIDE 4

The next slide shows data from an old experiment of mine with John Ballou (1l). Defined by the solid points, we see the same kind of body water curve as in the previous slide, except these rats were exposed chronically, for 6 months and the infiuence of organically bound tritium is more apparent, the curve breaking after less than a hundred-fold loss of body water activity. We measured the tritium level in the hydrogen from the organic matter of these rats--the open circles--and, you see, there was about $20 \%$ equilibration with body water hydrogen. That is, the specific activity of organic hydrogen was $20 \%$ of that of body water hydrogen. In some organs; e.g., brain, this was as high as nearly $40 \%$, and in fats, It was less than $10 \%$. That less than $100 \%$ equilibration occurred was, of course, reasonable, since not all organic hydrogen comes from drinking 
water. It also comes from water in food, and more significantly from the organic compounds of food, which were not labeled in this experiment.

The more crucial experiment, in which total hydrogen intake is uniformly tritium labeled, has not been reported. Such an experiment is in progress, however, at the Southwestern Radiological Health Laboratory, where Dr. Moghissi is feeding rabbits on a diet of barley, grown hydroponically, with tritiated water as virtually the sole source of hydrogen (12). An approach to such a uniformly labeled hydrogen intake has perhaps been achieved in some environmental studies that we may expect to hear about from Dr. Koranda.

Binding of tritium at non-exchangable sites in organic compounds of animal tissues, will, indeed, extend the period of exposure and increase the absoribed radiation dose beyond that attributable to body water. But all the organic hydrogen of the body is only half as much as the hydrogen in body water, so the total body dose, in a chronic exposure situation, could be increased only 50\% if there was total equilibration of organic hydrogen with body water tritium. There would seem to be only three ways to avoid that conclusion. First, there might be localized regions of higher dose due to localized concentration of hydrogen-rich compounds; but, water is about as hydrogen-rich as any compound ever gets, so we can forget that one. Second, tritium might be concentrated in certain compounds relative to ordinary hydrogen, i.e., an isotope effect. We have heard from Dr. Weston how such effects can occur. Several comparisons of tritium and deuterium incorporation in rats have grossly demonstrated such effects, however, the effects have been small, and discrimination was against tritium $(13,14,15)$. 
The third possibility is more troublesome. It is usually assumed that if a radionuclide is retained with a long half-time, its uptake is correspondingly low--if it has trouble getting out it will have the same trouble getting in. This, of course, is true only for a steady state system, which biological systems frequently approach--but not always. One can conceive of situations in which tritium might be easily incorporated and then retained with great tenacity--for example, if body water tritium levels were elevated during the period of oocyte formation, the DNA and other permanent organic constituents of these cells would contain tritium, which.would irradiate these cells from then until ovulation. The dose to these cells from their incorporated tritium, could be many hundred times that from the body water tritium that was sufficient to lable them initially. This possibility of dose multiplication, has, I think, not been studied with tritium oxide, and experiments that have been performed with tritiated thymidine are really not relevant to the more general hazard problem. Note, however, that while this situation could result in enhanced irradiation of the person unlucky enough to be exposed at a critical time, those persons exposed at other times will receive less exposure as a consequence of such non-steady-state conditions. In other words, this effect might increase the exposure of an individual, but, would not increase the total exposure of a population.

Let's now turn to toxicity studies. We are dealing with a very weak beta emitter--average energy about $6 \mathrm{KeV}$; average range in tissue about one micrometer. However, because of the fairly uniform distribution of water and of organic hydrogen in the animal organism, even on a micrometir scale, one can anticipate an esentially uniform total-body 
radiation exposure following tritium oxide intake; with the reservation that certain low-water-content tissues--like bone and fat--will receive a substantially lower exposure than the remainder of the body. There would seem to be only a couple of possibly complicating features of tritium toxicity. One of these has already been considered by Dr. Person-the question of possible transmutation effects--i.e., the damage sustained by a molecule that suddenly finds a helium atom where a hydrogen atom ought to be. The conclusion from cellular level studies seems to be that such transmutation effects do not add significantly to the ionizing radiation effects. I know of no animal studies that would dispute this conclusion.

The other possibly complicating feature of tritium toxicity is the question of the intrinsic biological effectiveness of such a weakly energetic beta. The LET of these betas is higher than that of more energetic betas or $x$ - or gamma rays, and a considerable effort has gone into attempts to demonstrate an RBE for tritium that is greater than unity. Although a number of values, based on a variety of experimental endpoints, have been reported in the range from 1 to 2 , the experimental uncertainty In most of these values is such that one feels little confidence ir accepting any particular value greater than one. Committee 2 of the ICRP adopted a value of 1.7 for its calculations of internal dose, in its 1959 report (16). However, it is likely that a value of one will be used in the next revision of this report.

The first animal toxicity study was performed by Brues and coworkers in the late 40 's (17). They determined the 30 day- $L D_{50}$ for intraperitoneally Injected tritium oxide in Cf-I mice, and arrived at a value of "about $1 \mathrm{mCi}$ per gram." Converting such an observation to radiation dose, and comparing 
with the effects from other radiation sources involves difficulties, since the tritium dose is extended in time and decreases with the half-time of body water in the animal. The $\mathrm{LD}_{50}$ of a mCi/g corresponds to a dose of about 300 rads during the first day postinjection. It will be convenient to bear in mind that a concentration of $1 \mathrm{mCi}$ of tritium per gram of unit density tissue will deliver a dose of 12 rads per hour, or about 300 rads per day. The $\mathrm{LD}_{50}$ for acute exposure to $250 \mathrm{Kv} \mathrm{X}$-rays is about $575 \mathrm{~V}$ for these animals: Brues, et al. concluded "that no unexpected factor of biological effectiveness exists..."

To simplify the time factor in these dose comparisons, Furchner performed a similar experiment in which the reference radiation, ${ }^{60}$ Co-gammas in his case, was delivered at an exponentially decreasing rate corresponding to the rate of loss of body water from the tritium oxide-treated animals (18). This was accomplished by means of a moving conical lead shield. His 30 day$\mathrm{LD}_{50}$ for $\mathrm{CF}-1$ mice was about $0.9 \mathrm{mCi} / \mathrm{g}$ corresponding to a total delivered dose of 804 rads. The $I D_{50}$ for ${ }^{60}$ Co radiation delivered at the same rate was 1350 rads, which leads to the conclusion that the tritium beta is 1.7 times as effective' as the ${ }^{60}$ Co gamma. As others have pointed out $(19,20)$, this RBE value for tritium would have been closer to one if $250 \mathrm{Kv} \mathrm{X}$-rays rather then ${ }^{60}$ Co-gammas had been compared, and if tritium dose to the non-bone, non-fat portion of the mouse were considered rather than average total-body dose.

In other studies of the $\mathrm{RBE}$ of tritium in mice and rats, dose was beld approximately constant over a five-day period by following an initial injection of tritium oxide with continuing feeding of an appropriate level of tritium oxide in the drinking water (21). Comparison was made with 
animals continuously exposed to ${ }^{226} \mathrm{Ra}$ or ${ }^{60} \mathrm{Co}$ gamma radiation. Sublethal

exposures were employed and effects noted on splenic atrophy, thymic atrophy, and depression of iron uptake by red cells. RBE's calculated from these end points ranged from 1.3 to 1.6 ; and, again would have been closer to one had $250 \mathrm{Kv} \mathrm{X}$-rays and dose to non-bone, non-fat tissue been compared.

These studies all date from 15 or more years ago. Subsequent interest centered largely on studies at the cellular level, which are outside my province, but which I might say demonstrated no unusual biological effectiveness.

Then, a few years ago, there was a resurgence of interest in tritium toxicity studies and there have been many recent reports of animal studies, particularly from the Soviet Union. The Russians report a 30 -day $L D_{50}$ in the rat of $1.03 \mathrm{mCi} / \mathrm{g}$, and a value in the mouse of $0.34 \mathrm{mCi} / \mathrm{g}$, which is lower by a factor of three than the earlier determined mouse values $(22,23)$. A recent Russian report compares acute toxicity from single doses of tritium oxide in the rat with external ${ }^{137}$ Cs radiation at dose rates simulating the pattern of tritium retention (24). RBE values ranged from 1.35 to 2.0 depending on the endpoint considered. Studies of many subacute effects of tritium oxide toxicity have been reported by the Russians (25-30). No unusual effects peculiar to tritium seem to have been noted. In dogs, $0.3 \mathrm{mCi}$ tritium oxide per gram, accumulating total doses of about $400 \mathrm{rad}$, was lethal (3I).

Recent studies in Russia $(32,33)$ and in this country $(34,35)$ have described the effects of in utero exposure to tritium oxide. Cahill, at the University of Rochester, maintained rats throughout pregnancy at body vater levels of 1 to $100 \mu \mathrm{Ci} / \mathrm{ml}$, corresponding to doses of about 0.3 to 
$30 \mathrm{rads} / \mathrm{day}$. The most sensitive parameters were gonad and brain weights noted at the $10 \mu \mathrm{Ci} / \mathrm{ml}$, or $3 \mathrm{rads} /$ day level. Compared to continuous it external gamma irradiation the tritium beta showed an RBE of 1.7, so, again we see no unusual effectivenss of tritium.

Effects of tritium oxide on the fertility of both male (36) and female (37) rats have been reported at single dose injections as low as $0.08 \mathrm{mCi} / \mathrm{g}$, corresponding to an initial dose rate of about $25 \mathrm{rads} / \mathrm{day}$. What is perhaps the most sensitive effect described for tritium oxide in animals is spermatogonial cell death in the mouse (38). This was evident at an injected dose of $2 \mu \mathrm{Ci} / \mathrm{g}$ body mass, which corresponds to a total dose of 1.2 rads over the 72 hour period of study. Compared with $200 \mathrm{Kv}$ $X$-rays delivered at an exponentially decreasing rate to simulate the tritium exposure, an RBE of 2.3 is indicated for the tritium beta in these studies. The effect of tritiated thymidine was also investigated in this experiment, and. was somewhat less effective than tritium oxide on the basis of estimated dose to cell nucleus; on an infected dose basis, the tritiated thymidine was four times as effective, per $\mu \mathrm{C} i$, as the tritium oxide.

In reviewing this literature, one is struck by the absence of truly chronic exposure studies, or studies involving lifetime observation following low exposures. There is a Russian report of chronic feeding, daily, for 60 days, but the lowest level fed was $5 \mu \mathrm{Ci} / \mathrm{g} /$ day, which probably resulted in an equilibrium dose of 30 to $40 \mathrm{rads} / \mathrm{day}$, and resulted in deaths shortiy following the feeding period (39). In one of our early experiments, we maintained rats, in utero, and chronically to the age of six months on a. tritium oxide intake that provided a radiation dose of about one rad per day (11). These animals were retained for as long as 300 days following 
the termination of tritium oxide feeding, and no gross effects were observed; however, this was a small number of animals and we were not looking for tóxic effects. Mammary tumors are noted in a Russian report as a long-term consequence of a single $0.3 \mathrm{mCi} / \mathrm{g}$ injection in rats, but no incidence figures are given (37). One hundred mice, injected at birth with $15 \mu \mathrm{Ci}$ tritium oxide which must have delivered a total dose of about 10 rads, were kept as controls in an experiment studying the carcinogenic effect of tritiated thymidine. No effects on mortality or tumor incidence were seen up to 27 months of age, when the surviving animals were sacrificed (40). Although I would expect no effects different from those of whole body external irradiation, I would like to see more data on long-term effects of low-level exposure to tritium oxide--particularly as this might be expressed in genetic effects. 


\section{REFERENCES}

1. G. N. Smith, R. J. Emerson, L. A. Temple, T. W. Galbraith, Arch. Biochem. Biophys. 46, 22 (1953).

2. E. A. Pinson, W. H. Langham, J. Appl. Physiol. 10, 108 (1957).

3. C. W. DeLong, R. C. Thompson, H. A. Kornberg, Radiation Research $\underline{\text {, }}$ $214(1954)$.

4. E. A. Pinson, Physiol. Rev. 32, 123 (1952).

5. I. G. Campbell, D. F. White, P. R. Payne, Brit. J. Radiol. 24, 682 (1951).

6. C. W. DeLong, Science 114, 397 (1951).

7. C. W. Delong, R. C. Thompson, H. A. Kornberg, Am. J. Roentgenol. Radium Therspy, Nuclear Med. 7I, 1038 (1954).

8. V. King, J. Physiol. (London), 200, 529 (1969).

9. C. R. Richmond, W. H. Langham, T. T. Trujillo, J. Cell. Comp. Physiol. 59, $45(1962)$.

10. R. C. Thompson, J. Biol. Chem. 200, 731 (1953).

11. R. C. Thompson, J. E. Ballou, J. Biol. Chem. 223, 795 (1956).

12. A. A. Moghissi, personal communication.

13. R. F. Glasscock, W. G. Duncombe, Biochem. J. 51, xi (1962).

14. M. L. Eidinoff, G. C. Perri, J. E. Knoll, B. J. Marano, J. Arnheim, J. Am. Chem. Soc. $\underline{75}, 248$ (1953).

15. R. C. Thompson, J. E. Ballou, J. Biol. Chem. 206, 101 (1954).

16. "Report of Committee II on Permissible Dose for Internal Radiation (1959)" Pergamon Press.

17. A. M. Brues, A. N. Stroud, L. Rietz, Proc. Soc. Exptl. Biol. Med. 79, $174(1952)$.

18. - J. E. Furehner, Radiation Res. 6, 483 (1957).

19. V. P. Bond, L. E. Feinendagen, Health Physics 12, 1007 (1966). 
20. J. Vennart, Health Phys. 14, 541 (1968).

21. J. B. Stover, P. S. Harris, J. E. Furehner, W. H. Langham, Radiation Res. 6, 188 (1957).

22. V. F. Zhuravlev, P. F. Bugryshev, A. G. Istomina, Radiobiologiya $\underline{6}$, $59(1966)$.

23. V. F. Shuravlev, P. F. Bugryshev, A. G. Istomina, "Raspredolenie i. Biologicheskoe Deistvie Radioaktivnykh Izctopov," Atomizdat, Moscow, 1966, p. 182 [AEC-tr 6944, p. 235]

24. Y.-I. Moskalev; V. F. Zhuravlev, D. A. Kazbekova, Radiobiologiya 10, 422 (1970) [N.S.A. 25:593].

25. G. A. Shelnova, V. F. Zhuravlev, Radiobiologiya 6, 259 (1966) [NSA 21:8985]

26. K. A. Veselovskaya, R. M. Lyubimova-Gerasimova, V. F. Zhuravlev, Radiobiologiya I, 525 (1967) [NSA 22:19412].

27. G. A. Shelnova, V. F. Zhuravlev, T. D. Kuzmina, Radiobiologiya $\underline{8}$, 872 (1968) [NSA 23:17949].

28. G. A. Shelnova, T. D. Kuzmina, "Raspredelenie i Biologicheskoe Deistvie Radioaktivnykh Izotopov," Atomizdat, Moscow, 1966, p. 196 [AEC-tr-6944, p. 251.].

29. D. A. Kazbekova, ibid. p. 211 QAEC-tr-6944, p. 269].

30. V. F. Zhuravlev, O. Y. Tereshchenko, ibid, p. 215 [AEC-tr-6944, p. 274 ].

31. G. A. Shelnova, V. F. Zhuravlev, Radiobiologiya 6, 863 (1966) [NSA $21: 36720]$.

32. A. M. Lyaginskaya, Med. Radiol. 10, No. I, 33 (1965) [NSA 19:17579].

33. A. M. Lyaginskaya, I. V. Zhokova, "Raspredelenia i Biologicheskoe Deistvie Radioaktivnykh Iznt.opnv," Atomizdat, Moscow, 1066, p. 391 [AEC-tr-6944, p. 493]. 
34. A. M. Lyaginskaya, I. V. Zhokova, "Raspredelenia i Biologicheskoe Deistvie Radioaktivnykh Izotopov," Atomizdat, Moscow, 1966, p. 391 [AEC-tr-6944, p. 493].

35. D. F. Cahill, USAEC DOC. UR-49-1254 (1970) [NSA 24:23356].

36. V. F. Zhuraviev, A. M. Lyaginskaya, "Respredelenie i Biologicheskoe Deistvie Radioaktivnykh Izotopov, Atomizdat, Moscow, 1966, p. 399 [AEC-tr-6944, p. 503].

37. A. M. Lyaginskaya, ibia, p. 202 [AEC-tr-6944, p. 258].

38. B. E. Lambert, Health Phys. 17, 547 (1969).

39. V. F. Zhuravlev, "Raspredelenie: Biologicheskoe Deistvié Radioaktivynkh Izotopov," Atomizdat, Moscow, 1966, p. 188 [AEC-tr-6944, p. 242].

40. R. Baserga, H. Lisco, W. E. Kiesieleski, Radiation REs. 29, 583 (1966). 
VOLUME AND TURNOVER OF BODY WATER ${ }^{(a)}$

\begin{tabular}{|c|c|c|c|}
\hline \multirow[b]{2}{*}{ SPECIES } & \multirow[b]{2}{*}{ WT $(g)$} & \multicolumn{2}{|c|}{ BODY WATER } \\
\hline & & $\%$ OF BODY,WEIGHT & HALF TIME (d) \\
\hline MOUSE & 20 & 58 & 1.1 \\
\hline KANGAROO RAT & 90 & 62 & 12. \\
\hline RAT & 300 & 60 & 3.5 \\
\hline RABBIT & 3,000 & 58 & 3.9 \\
\hline DOG & 10,000 & 66 & 5.1 \\
\hline MAN & 70,000 & 55 & 9.5 \\
\hline HORSE & 400,000 & 66 & 8.4 \\
\hline
\end{tabular}

(a) Data from C. R. Richmond, W. H. Langham, T. T. Trujillo, J. Cell. Comp. Physiol. $\underline{59}$ 45 (1962)。 
slide 2

INTERSPECIFIC CORRELATION BETWEEN LOG DAILY. WATER LOSS AND LOG BODY WEIGHT ffrom C. R. Richmond, W. H. Langham, T. T. Trujillo, J. Cell. Comp. Physiol. 59, 45 (1962)).

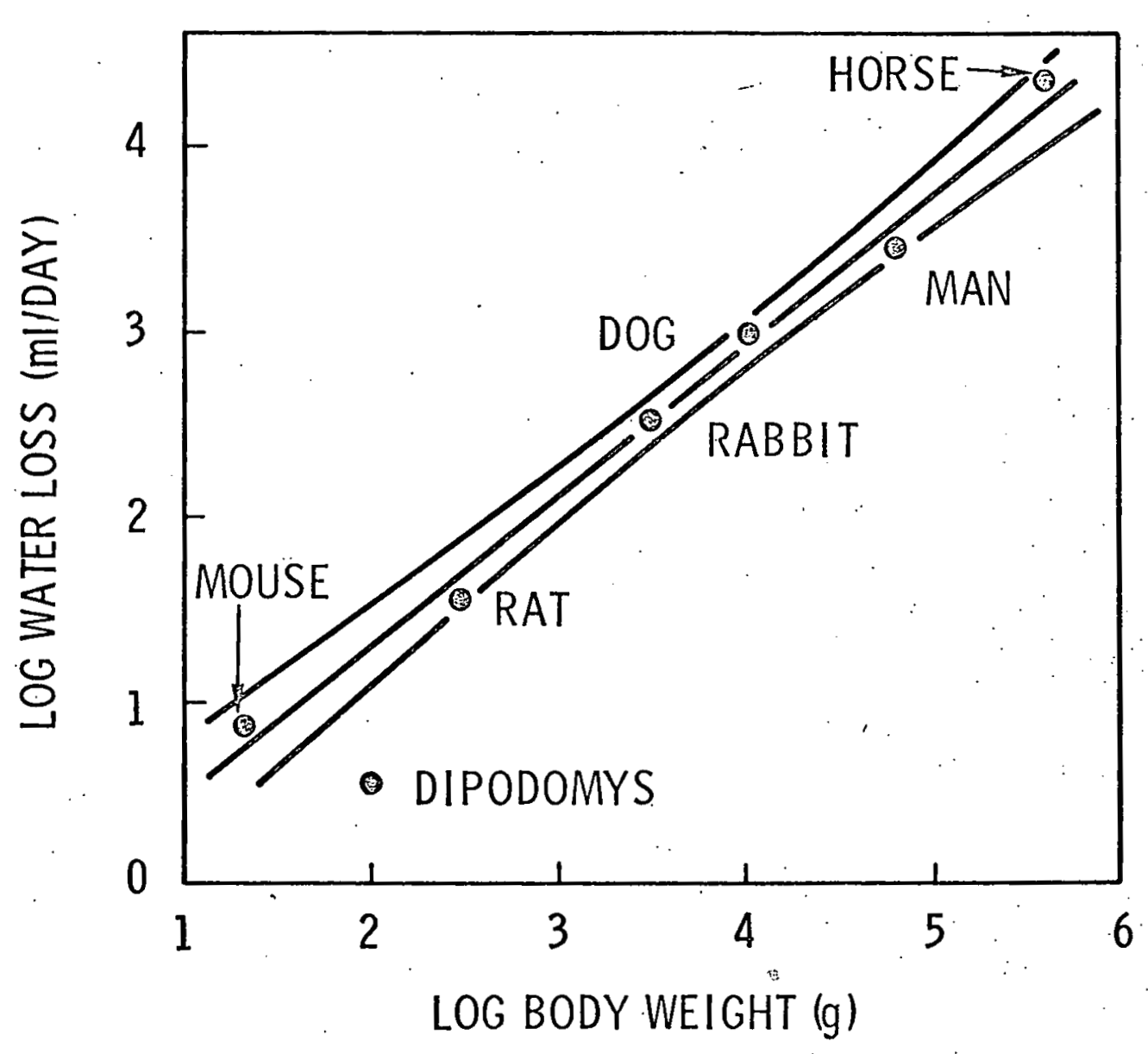


Slide 3

RETENTION OF TRITIUM IN THE BODY WATER

OF THE RAT (from R. C. Thompson, J. Biol. Chem. 200, 731 (1953)).

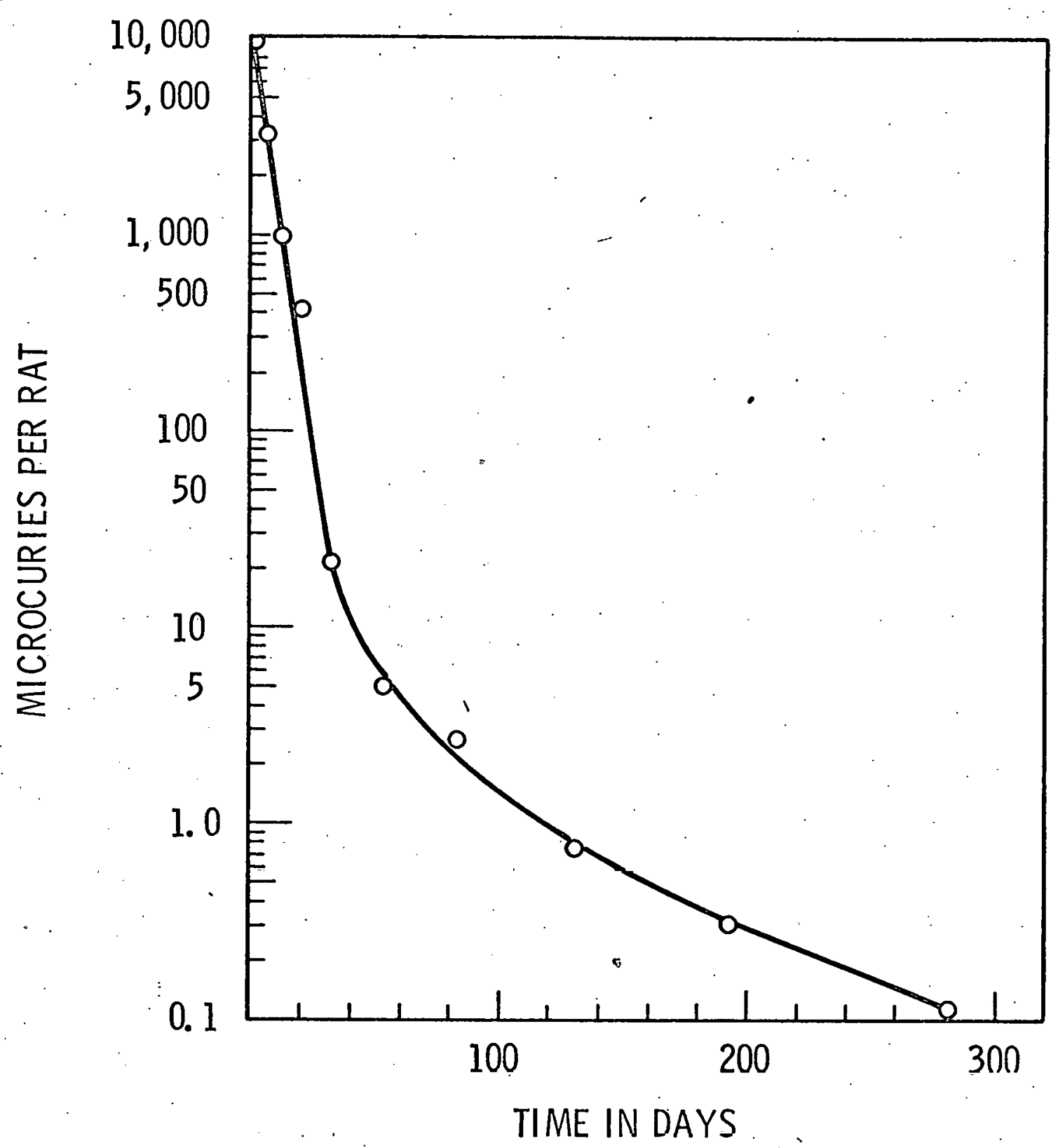


RETENTION OF BODY WATER TRITIUM

AND ORGANICALLY-BOUND TRITIUM IN RATS

AFTER CHRONIC EXPOSURE TO TRITIUM OXIDE

FROM CONCEPTION TO AGE 6 MONTHS

(from R. C. Thompson, J. E. Ballou, J. Biol. Chem. 223, 795 (1956)).

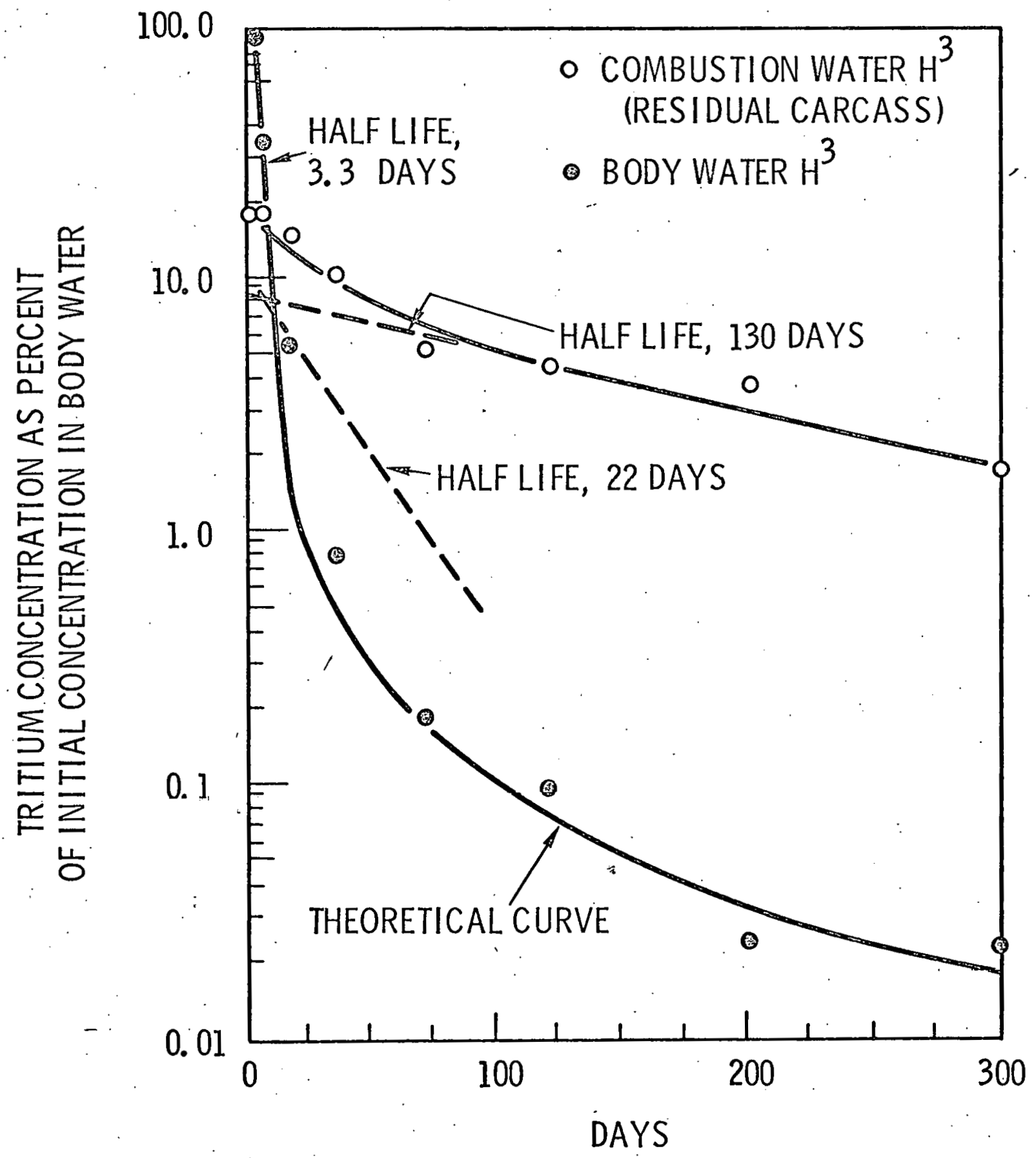

